\section{BUDDHISM IN ITALY IN THE NINETEENTH CENTURY ${ }^{1}$}

Paolo Euron ${ }^{2}$

บทคัดย่อ

รายงานเกี่ยวกับพุทธศาสนามาถึงประเทศอิตาลีเป็น ครั้งแรกในราวคริสตวรรษที่สิบหก ผ่านทางคณะ มิชชันนารีของอิตาลี ในเวลาต่อมานักวิชาการ ได้ พัฒนาความเข้าใจด้านภาษาและปรัชญาเกี่ยวกับ พุทธศาสนา ท่าทีต่อพุทธศาสนาได้เปลี่ยนจากความ สนใจด้านมานุษยวิทยา มาเป็นการศึกษาด้านภาษา ในการศึกษาด้านนิรุกติศาสตร์ ประเพณีของเถรวาท และพระไตรปิฎกฉบับของสยามมีความสำคัญมาก การแพร่กระจายของพุทธศาสนาในอิตาลีใน คริสตศตวรรษที่สิบเก้า ก็ได้รับอิทธิจากวัฒนธรรม และแนวคิดต่างๆของอิตาลีด้วย ในบรรดาผู้ที่อยู่ นอกวงการวิชาการ พุทธศาสนาได้กลายเป็นหัวข้อ ของการพยายามแก้ต่าง และของวิชาปรัชญา รวม ไปถึงหัวข้อที่คนทั่วไปสนใจ บทความอาศัย หนังสือและเอกสารสิ่งพิมพ์ที่ตีพิมพ์ในประเทศ อิตาลีเกี่ยวกับพุทธศาสนาในคริสตศตวรรษที่สิบเก้า

${ }^{1}$ (พระพุทธศาสนาในอิตาลีในคริสตวรรษที่สิบเก้า) This essay has been written with the support of the Faculty of Arts, Chulalongkorn University, Bangkok.

${ }^{2}$ (เปาโล ยูรอน) $\mathrm{Ph}$. D., Lecturer, Department of Western Languages, Faculty of Arts, Chulalongkorn University, Bangkok, Thailand.
เอกสารที่อ้างอิงบางชิ้นในบทความนี้ไม่เคยตีพิมพ์

มาก่อน หรือเป็นเอกสารหายากจากหอจดหมายเหตุ ในประเทศอิตาลี

\section{Abstract}

First reports on Buddhism arrived in Italy in the sixteenth century through Italian Catholic missionaries. Later several scholars developed a philological and philosophical understanding of it. The attitude toward Buddhism changed from an anthropological interest to a philological study. In the academic field of philology the Theravāda tradition and the Siamese edition of Tripitaka had great importance. The spread of Buddhism in Italy in the nineteenth century also increasingly influenced Italian culture and ideas. Outside of academic debate Buddhism became a subject of apologetics and philosophy as well as a topic of general interest. This essay is based on books and printed material published in Italy before the twentieth century. It contains the complete bibliography of Italian studies on Buddhism in the nineteenth century. Some texts cited in this essay are unpublished or rare documents from Italian archives.

\section{Introduction}

The first accounts of Buddhism in Italy arrived through the memories and writings of Italian Catholic missionaries coming back from the Far East in the sixteenth century. These descriptions of another philosophical and religious tradition, so different from the Classical culture of 
Europe, conjure up an idea of Buddhism which is vague and imprecise, as well as fascinating.

Interestingly, a century later, many authors still show a certain superficiality in dealing with the subject. "Interest in Buddhist studies in Italy, so flourishing in other European lands, has started very late" (Botto 1997: 101). The slow spread of Buddhism in the nineteenth century shows two different effects on Italian culture. On one side, we can state an enthusiastic appreciation of Buddhism; on the other side Buddhism is considered a threat with some authors attempting to show its limits and inferiority to the Christian religion. On the other hand several distinguished scholars develop an adequate understanding of Buddhism, opening a field of study from a philosophically and philologically correct perspective.

Oscar Botto, in his essay Appunti per una storia degli studi Buddhisti in Italia (Notes on the History of Buddhist Studies in Italy), writes that there are three different phases in the Italian history of Buddhist studies: first of all, there is a phase of almost uncritical acceptance of documents on Buddhism from different sources, considered without the right background and without adequate philosophical and philological tools. Then there is a middle phase, in which we can appreciate a development of critical skills along with the refinement of a philosophical and philological consciousness of the subject. This awareness leads to the third period, in which there is a fully developed critical and scientific attitude to Buddhism (1985: 175).

In this essay the description of the evolution of Italian Buddhist studies is not strictly chronological and we will take into account the most significant authors and their works. Nevertheless, since we are researching in a delimited chronological frame, we will consider above all the first and second phases and only some examples of critical consciousness and adequate method, for instance Pavolini's excellent book Buddismo (1898). In other words, we will consider the period of uncritical enthusiasm for Buddhism and the open criticism against it and, after that, the origins of a correct philosophical and accurate philological method in Italian Buddhist studies.

\section{First reports on Buddhism}

Since the beginning of the seventeenth century, reports of travelers and missionaries stoked an interest in the "East" and in Asian philosophical and religious traditions. As a consequence of that, some Western thinkers viewed Buddhism in its peculiarity. From Gottfried Wilhelm Leibniz (1646-1716) to Ralph Waldo Emerson (1803-1882), from Henry David Thoreau (1817-1862) to Arthur Schopenhauer (1788-1860) Buddhism was considered as a theoretical system and as a new intellectual perspective, which was often unclear and confused with Hinduism. Nevertheless, in many Western authors it appeared to be a consistent belief. In 1844, the French scholar Eugène Burnouf (1801-1852) proposed a systematic and influential 
interpretation of Buddhism, and soon after, in France, Germany and England, Buddhism was considered as a speculative fact rather than as a religious practice. We have to consider that the first contact with Buddhism occurred through written texts separated from the cultural background and real experience of it. (see Filoramo 2007: 377)

What happened in Germany, England, the United States and France did not happen in Italy. At the beginning of the eighteenth century, there is in Italy no cultural interest in or curiosity about Buddhism. Though the first travelers to India and the Far East were Italian, they brought back to Italy above all geographical descriptions, historical reports and commercial notes. In 1867 Angelo de Gubernatis describes the contribution of Italian travelers to the knowledge of the Far East in his book Memoria intorno ai viaggiatori italiani nelle Indie Orientali (Memoire about Italian travelers to East India). From Marco Polo to the sixteenth century travelers reported unsystematically on geography, history and commerce. There is little information about language. Facts about culture and religion are very general and poor. In his book Milione Marco Polo uses the very generic expression "they worship idols" in order to describe the religious practices of many different nonMuslim peoples. The Italian travelers notice rather the extravagance of these religious practices and show little interest in the rest. (See de Gubernatis 1867b: 137).

The first Italian scholars of Oriental studies considered the contribution of
Italian missionaries. Actually missionaries were the only Italians interested in the religious and philosophical aspects of Asian cultures. De Gubernatis writes in his Matériaux pour servir à l'Histoire des Etudes Orientales en Italie [Materials to use for the History of Oriental Studies in Italy]

Il est hors de doute qu'il revient aux missionaries italiens le mérite d'avoir les premiers apporté en Europe une notice de la region asiatique la plus impenetrable. [...] Il est surtout à regretter que cette etude soit resté en Italie le privilège des missionaires, qui n'avaient certainement aucun intérêt à nous donner une idée exacte du bouddhisme. (1876: $367,376)$

[No doubt that Italian missionaries have the merit to be the first to bring to Europe news from an Asian region among the most impenetrable. (...) It is a pity that in Italy such a study remained the privilege of missionaries, who definitely had no interest in giving us a precise idea of Buddhism.]

In 1876, Carlo Puini announced the recovery of an ancient report written by the Jesuit missionary Ippolito Desideri (1684-1739) who went to Tibet in 1713. In this book, Di una relazione inedita del viaggio al Tibet del padre Desideri (Unpublished Report of Father Desideri's Travel to Tibet) Father Desideri declares that he travelled to Tibet in order to bring the Catholic religion. There he meets 
Buddhist monks; he is touched by the kindness and tolerance of the people in Lhasa, where he can study the Tibetan "Kaa-n-ghiur" which living in a Buddhist temple "where the monks transformed a room into a Catholic chapel" (Puini 1876: 37). Desideri is able to study the Buddhist religion and to read the original texts, but his aim is to fight Buddhism and to show its supposed errors. Desideri is the first European scholar of Tibetan Buddhism, but he fails to undertake a scientific and philological study. His only interest is an apologetic one. He does not offer a systematic analysis of the Tibetan Buddhist canon, despite the long time he spent on it. Since his writings on the Buddhist canon are just an attempt to criticize it, the description of it is quite approximate: 'the 'Kaa-n-ghiur' is a work of about 115 to 120 books, translated from the ancient, scientific language of Hindustan into Tibetan" (Puini 1876: 41).

In 1899, Carlo Puini presents some selected abstracts concerning Buddhism from Desideri's report, Il Buddhismo nel Tibet (Buddhism in Tibet) along with a careful introduction, Il p. Ippolito Desideri $e$ i suoi viaggi nell'India e nel Tibet (Father Ippolito Desideri and his travels to India and Tibet). Puini writes that Desideri was the first who had "a clear and precise idea of Buddhism" (1899: XXII). Nevertheless, Desideri does not use the name 'Buddha' and he does not consider the Tibetan religion as a form of Buddhism, but rather as a Tibetan form of Indian paganism (Puini 1899: 13). He understands that there is no personal God in Buddhism as in the revealed religions (10) and he seizes on the importance of metempsychosis in the Buddhist system, but his work is an external, almost anthropological description of rites, beliefs and customs.

It is worth remembering that Italian scholars in the eighteenth century, thanks to the influence of European translations and studies (rather than because of Desideri's report), consider the Tibetan canon as the first and most important source of Buddhism, along with Chinese translations. The publishing of the Siamese Tipitaka in 1884 (see the paragraph 'The Siamese edition of the Tipitaka and the new scientific approach') and the general European interest in the Pali canon will change the situation, and from then on attention will focus on Theravāda Buddhism.

Most of the reports, writings and manuscripts of early missionaries are lost. Emilio Teza cites the travels of Giovanni Maria Percoto (1729-1776) to Burma in Voci birmane nella vita del padre G. M. Percoto. (Burma Voices in Father Percoto's Life) (Teza 1895-96) This is a long review of Michelangelo Griffini's Della vita di Mons. G. M. Percoto (...) missionario ne' regni di Ava e Pegu libri tre scritti dal padre M. G. (Griffini 1781). In his review Teza states that Percoto's books (a Burmese dictionary, a grammar and a catechism) should be available in the Library of Propaganda Fidei in Rome. But Teza himself writes that they are untraceable. (Teza 1895-96: 3) Actually, even a catalogue published in 1876 by Angelo de Gubernatis, Manoscritti indiani del Museo Borgiano nel Collegio di Propaganda, (de Gubernatis 1876a) does 
not mention such writings. Nevertheless, a treatise on Buddhist rituals translated by Percoto was current in the European debate on Buddhism. In 1896 Henry Clark Warren, after attending at a Buddhist ordination service in Ceylon, writes in his Buddhism in Translation:

After witnessing the celebration of this rite, I read the UpasampadâKammavâcâ or book setting forth the form and manner of ordering of priests and deacons, and I was subsequently induced to translate it. This manual was translated into Italian in 1776 , by Padre Maria Percoto (missionary in Ava and Pegu), under the title of Kammuva, ossia trattato della ordinazione dei Talapoini del secondo ordine detti Pinzi, and a portion of it was edited in 1841, in Pâli and Latin, by Professor Spiegel. Clough translated it in 1834, and Hardy has given an interesting summary of it in his Eastern Monachism; but neither the text nor any complete translation is readily accessible, and I have therefore thought that this edition might possibly be acceptable to those who desire information respecting the practice of Buddhism in Ceylon, where, as is well pointed out by Mr. Childers, in his Pâli Dictionary $[\ldots]$ "Buddhism retains almost its pristine purity." (Warren 1896: 394)

Even though Carlo Puini writes in his book Buddha, Confucio, Lao-Tse of the ritual book named Kammavâtya «translated for the first time into Italian by Padre Maria Percoto under the title Kammuva» (Puini 1878: 218) and of its effects on European Buddhist studies, according to Puini, the manuscript was already untraceable.

\section{Indian Buddhism}

Buddhismo Indico (Indian Buddhism) is an interesting short text written by Gaspare Gorresio. It is a letter from 1845, addressed to Costanzo Gazzera, secretary of the Royal Academy of Science of Turin. Gazzera was a collector of ancient manuscripts who gave Gorresio a mysterious code. Gorresio recognizes that it was an ancient Buddhist code written in Pali language and Burmese characters.

Gaspare Gorresio (1801-1891) was the founder of Italian Oriental studies. Born in Piedmont, he studied in Turin and Vienna, then in Paris with Burnouf, and in 1852 he gave the first course of Sanskrit at the University of Turin. He received many acknowledgments and in 1868 he became secretary of the Academy of Science of Turin. With Gorresio Turin becomes the most important Italian city in the field of Oriental studies, and since then many Italian scholars (see the next paragraph) have received their education at this university. In 1845, Gorresio wrote to Gazzera that he was not working on the great religious, philosophical and social system of Buddhism so that he could "decipher a Buddhist, or Cingalese, or Siamese, or Burmese code" (Gorresio 1845: 2). Gorresio displayed a correct understanding of the spread of Buddhism from India to Siam and Burma, to China 
and Tibet, and subsequent translations of the Buddhist canon from Pali to local languages. The code presented by Costanzo Gazzera was the Kammavakya, the ritual book (see above the report about Percoto's translation), and in his letter, Gorresio gives a short summary of it.

Gazzera gave his collection of manuscripts to the Royal Academy of Science of Turin. Now it would be very interesting to know if the Kammavakya code cited by Gorresio is the same manuscript translated by Father Maria Percoto. In any case, it is interesting enough to highlight that the first sources of Buddhism in the Italian debate were ritual texts in Pali, though they could not have been understood adequately as the Italian academic milieu was not ready. "Gorresio, back from his long stay in Paris, remained completely outside the flowering of this new and fascinating discipline [Buddhist studies]. On the contrary, it is very likely that he brought back with him to Turin stimulating information about that fertile cultural world" (Botto 1997: 101).

\section{Scientific and Anthropological Approaches}

The abbot Gaspare Gorresio, who first introduced the study of Sanskrit language and literature to Italian universities, was the first representative of the "School of Turin" of Indology. He edited and translated the Ramayana of Valmiki in a careful and philologically correct edition (1843-1850). Philological care and a scientific attitude are characteristic of Indology scholars of the Turin school. Several distinguished professors educated at the University of Turin went on to teach Sanskrit and continued the tradition of Indian studies. They included Giovanni Flechia (1811-1892), Domenico Pezzi (1844-1905), Italo Pizzi (1849-1920), Mario Vallauri (1887-1964), and Oscar Botto (1922-2008). Many scholars educated at the University of Turin carried the discipline of Indology to other Italian universities: Giacomo Lignana (18301891), after studying Indology in Turin and in Germany, taught at the University of Naples and Rome; Michele Kerbacher (1835-1914), with interests in comparative philology and science of religions, taught in Naples; Angelo de Gubernatis (18401913), after studying linguistics and Sanskrit in Turin and Berlin, taught Sanskrit in Florence and Rome and wrote many literary works and several studies on Indology and Buddhism; Pietro Merlo (1850-1905) taught in Naples and Pavia; Oreste Nazari (1866-1923) worked in Palermo.

On one side, we can state that now, in the tradition of the school of Turin, many scholars in the academic world of Oriental studies paid a special attention to the philological aspect of the text. On the other side, we have to take into account that studies on Asian culture, religion, traditions and specifically on Buddhism were generally considered as a part of Indology. As already stated, Indian, Tibetan and Chinese traditions were considered the primary sources of Buddhism.

Carlo Puini (1839-1924) is a prolific scholar of Oriental studies, studied in Pisa, and from 1877 to 1920 , he taught "history 
and geography of East Asia" in Florence. $\mathrm{He}$ was interested in China, Tibet and Japan and, in his studies, he dealt with the connection between historical, artistic and religious aspects of Far Eastern cultures. His pioneering activities were very important to Asian studies in Italy, and he wrote some pivotal essays, introducing a scientific (though sometimes generic) view of Buddhism to Italian culture.

As we have already seen, Puini presented a report on Percoto's travels to Tibet and his work there (1876). Some years before, between 1871 and 1873, he published five essays in which he dealt with the main tenets and problems of Buddhism. These essays (Puini 1871a; 1871b; 1872a; 1872b; 1873), which appeared in «Archives of Anthropology and Ethnology», reflect an historical and anthropological interest, so that Buddhism seems to be a great, and sometimes dazzling cultural and religious phenomenon. These essays were essentially based on French (Burnouf), English (Hardy), German (Koeppen) and Russian (Wassiliew) translations and studies, and they present the life and works of Buddha, the spread and development of Buddhism, Buddhist metaphysics, and the concept of Nirvana and its development in different cultures. Puini displays a broad cultural knowledge and an impressive ability to connect different aspects of Buddhism, though he remains rather focused on Chinese and Tibetan civilizations. Even so, his work is quite general and seems to be a convincing attempt to popularize Buddhism.

In his book Buddha, Confucio, Lao-Tse, Puini writes that "language and religion are what constitutes a people, more than blood." (1878: IV) Starting from this point of view, he displays a great philological care and a special attention to literary texts in order to understand the essence of a culture. His secondary sources on Buddhism are, as in his previous works, French, English and German studies. As a consequence of that, and as a consequence of his general interests, his primary sources on the Buddhist canon are Tibetan and Chinese texts, and their French and English translations. He deals above all with Chinese Buddhism; the South East Asian tradition, as well as the Pali canon, are considered relatively seldom in his writings. But, interestingly enough, Puini writes that the Siamese version of Buddhism is the most original and pure and that it has a moral superiority to other forms of Buddhism (1878: LVII-LXII). Moreover, he writes that the "Pali collection (...) preserves the most ancient and genuine doctrine" (1878: 210). Puini's general survey was not conceived for scholars but as a popular explanation written for educated readers even without a specific knowledge of the subject. Buddhism is on the way to becoming a topic of general interest.

Puini's cultural and general approach characterizes the Enciclopedia sinicogiapponese (Chinese-Japanese Encyclopedia) (1877) too, a book which translates and comments on a selection of religious, traditional, historical excerpts from the Japanese encyclopedia Wa-kan san-sai tuye concerning Chinese and Japanese Buddhism. In this work Puini shows a great philological care in dealing with names concerning Buddhist history and 
rituals, the architecture of temples, usual objects, and heroes' names from Japanese legends, and always he compares the Sanskrit, Chinese and Japanese origins of each term.

In the same year Angelo de Gubernatis wrote a flattering review of Puini's work, defining it as "an important work in the history of Buddhism." (de Gubernatis, 1877) At any rate, the result was that Puini definitely moved the attention of Italian scholars to the Chinese and Japanese traditions of Buddhism. De Gubernatis himself, with his broad cultural familiarity and his first-rate European education in linguistics and Sanskrit (he studied in Berlin with Franz Bopp and Albrecht Weber) privileged Indology and concentrated his attention on India, Indian myths and anthropological aspects of Indian culture. His writings were very important in developing Asian studies in Italy though, in this case too, we have to take into account their pioneering character and their limits. His contribution to the study of Buddhism concerned essentially Indian Buddhism. In his Letteratura Indiana (Indian Literature) de Gubernatis states that Buddhism gave a literary dignity to traditional and popular legends about animals, which later spread through Asia to China, Japan and Tibet and, thanks to the Arab and Hebrew translations, to Europe. (See de Gubernatis 1883: 73-75) Already in 1867, in his early Piccola enciclopedia Indiana, de Gubernatis presents a general overview of Indian terms and concepts. Sanskrit words are carefully explained and compared to Indo-European terms and, as far as Buddhism is concerned, names and concepts are presented in their philological, historical and cultural background.

Budh root (compare bud, [bund, bundh, c'ud roots, to watch, to perceive, to understand]) to wake up, to be awake, to understand, to be aware, to know (Max Müller noticed the analogy between the dawn, which in the Vedic Hymns is named "the awakener" and "the first to be awake" and Athena or Minerva or wisdom) to observe, to perceive, to learn, to be of the opinion, to repute, to be cautious. So, among other derivatives, the following: budha, as an adjective, awakening, cautious, intelligent, wise, as a masculine noun, the wise man (to be understood as the source of light, the enlightener, the one who gives wisdom) appellation of the planet Mercury considered as the son of Soma and of father Purùravas; buddhi feminine noun, intelligence, intellect, understanding, wisdom [...] Buddha masculine noun, the enlightened one, the enlightener, the one who brings the light, the wise man. Because of this general appellative we can understand that several Buddha have been imagined in India, it means several wise enlighteners. Nevertheless the Buddha, the most famous among the Buddha, is the one named Şàkyamuni, who really existed. [...] (de Guberbatis 1867a: 469) 
By these means, de Gubernatis highlights the specificity of Buddhist concepts and the impossibility of reducing them to the Western mindset and of explain them by means of Western concepts. (See the term 'nirvana', de Gubernatis 1867a: 414). De Gubernatis attitude to Buddhism was scientific and he kept a certain distance from the subject. Nevertheless, thirty five year later in 1902 he published an historical-philosophical drama on Buddha's life and teachings. The five-act play is written in verse and is interesting from a literary point of view, but it is above all of a great cultural interest, since it attests the spread of Buddhism beyond the academic and technical fields. Buddhism has become a general issue and now it is felt, and presented, as an artistic and cultural topic.

\section{The Siamese Edition of the Tipitaka and the New Scientific Approach}

In 1894 H. M. King Chulalongkorn promoted the publishing of the first edition of the Pali Buddhist Canon of Tipitaka printed in Siamese characters. Several of these books were donated to Western universities and institutions. A copy of this edition of the Tipitaka with the inscription "Tipitakam dei Buddiani, (...) (in lettere Siamesi) Bangkok, 1894" [Buddhist Tipitaka (in Siamese characters) Bangkok, 1894] donated to the Royal University of Turin is still available at the National Library of Turin. Another copy is still present in the Academy of Science, with a similar inscription, given by King Chulalongkorn to the Royal Academy of Science of Turin more than 120 year ago. (See below the chapter "Sources"). The inside cover is a printed sheet in Thai, English, French and German which gives this information:

This edition of the sacred writings of the Southern Buddhists the Tipitaka has been published by order of His Majesty Somdetch Phra Paramindr Maha Chulalognkorn Phra Chula Chom Klao King of Siam on the $25^{\text {th }}$ anniversary of his ascension to the Throne and is presented by him in commemoration of this event. To Reale Universita de Porino (sic).

King Chulalongkorn used the expression "Southern Buddhists" to mean Theravāda Buddhism in contrast to other traditions. In doing so he defines the Siamese Buddhist identity in a time when the term "Theravāda" was not yet in use. (Sheravanichkul 2012: 430)

This edition of the Tipitaka, in Pali language and Siamese characters, changed the study of Buddhism in Italy. For the first time scholars had a complete and philologically accurate edition of the Pali canon in Siamese characters.

A short introduction by Emilio Teza (1831-1912) was enclosed will the Tipitaka. The same small text was available as a separate book, too. Teza welcomes the "wonderful present" (1896: 214) of King Chulalongkorn and writes that further copies have been donated to the Academy and to the University of Padua. He briefly describes the structure and the content of the 39 volumes and 
highlights the convenience of the Siamese alphabet in the transcription of the Pali text. At the same time, Teza makes some philological remarks on the text and compares it to Western editions, which are sometimes more accurate but not complete.

Teza's perspective is strictly philological and he collated the Siamese text with the text of Western editions of Tipitaka and single Pali words and expressions with the Sanskrit ones. This scientific and linguistic approach characterizes Emilio Teza's work. More than Buddhism, he considered the language in which texts were written. In doing so he marked a new stage in the research on Buddhism.

Two years later, Paolo Emilio Pavolini (1864-1942) wrote the most historically and scientifically correct, clear and balanced Italian introduction to Buddhism. Pavolini's Buddismo (1898) is a general and consistent introduction to the subject and can still benefit readers even today. He deals with the life of the Buddha, with the Dhamma (Law), the Sangha (Order) and the Tipitaka. A chapter is dedicated to Buddhist studies and (more or less) critical editions of Buddhist sources, Western as well as Asiatic. Special attention is given to the Pali canon, and Pavolini uses the Siamese version of King Chulalongkorn (114) from which he gives some examples of translation. His book is not only a philological work for scholars but an attempt to present the gist of Southern Buddhism to common readers. Pavolini's interpretation of Buddhism is based on philosophy and philology. Even a comparison of the Tipitaka to the Christian
Gospels shows the specificity and depth of Buddhism. (40) Times were now ripe, even in Italy, for a scientific approach and a philosophic understanding of Buddhism. Nevertheless the calm and detached attitude of Pavolini was not the common spirit in the general cultural and religious debate involving Buddhism and Christian tradition.

\section{From Philology to Philosophy and to Apologetics}

Italian scholars have, in general, had a lay attitude towards Buddhism so that they have discussed its philosophical and religious aspects at a distance and sometimes even with a certain coldness, as if they were dealing with mere anthropological facts. For example, in his essays on the history of religion, Puini (1882) deals with metempsychosis, karma and Nirvana in a very general and detached way. In 1897, while European and Italian attention was more and more focused on the Pali canon and on the correct interpretation of philosophical aspects of original Buddhism, Puini published a translation of the Chinese version of Saddharmapundarika (Puini 1897) confirming his continuing philological and historical interest in the Chinese Buddhist tradition. We have to highlight that, in the nineteenth century, there were few Italian translations of Buddhist texts, except the selection of excerpts presented in scientific essays, and usually these excerpts were retranslated from other European languages. The Italian debate on Buddhism was usually based on interpretations, not (or not primarily) on texts. Only in 1912 Pavolini 
translate some texts of Buddhist morality, and Carlo Formichi translated Asvaghosa's Buddhacharita within the limits of his age, Puini showed a consistent research approach, broad cultural understanding, a philological attention. Above all, he remained a model of open minded scholarship with a nonconfessional attitude.

Michele Kerbacher, director of the Collegio Asiatico in Naples and Professor of Sanskrit, developed a compared study of mythology. Philology and reflection on language, poetry and myths became a way to understand a culture. From this perspective he proposed a "science of religions" so that "theology becomes more rich and perfect through the contributions of philology and history" (Kerbacher 1882b: 43). Though Kerbacher does not deal directly with Buddhism, his perspective proposes a dialogue and a confrontation between scientific and philological understanding and religious traditions.

Since 1890 a new attitude began to arise in the Italian debate on Buddhism. Scholars' interest shifted from an historical and philological perspective to a philosophical or rather religious and confessional one. In the last decade of the nineteenth century, some authors did not understand Buddhism as an object of historical or scientific knowledge, but as a term for religious comparison and, usually, as a threat to the Christian religion. In 1890, Raffaele Mariano published Buddhismo e Cristianesimo (Buddhism and Christianity) in it. He states that there are more and more studies on Buddhism and that the idea of its superiority to the Christian religion has spread beyond academic circles and "has become a general matter of everyday talk." (1890: 4) Mariano took into consideration, above all, French sources (Eugène Burnouf, Eduard Schuré) and German thinkers and scholars (Arthur Schopenhauer, Eduard von Hartman, Max Müller, Hermann Oldenberg). Mariano condemned the religious syncretism of Buddhism and defended the originality and authenticity of Christianity and its clear superiority in metaphysical and moral issues. According to Mariano, Buddhism demonstrates a social and historical lack of efficiency, it is against humanity and against civilization, since civilization is a synonym for Christianity. The intention to write a "comparative study" failed and the book is a one-sided apology of the Christian faith of little philosophical interest and, today, of mere historical relevance.

In the same year Enrico Catellani wrote a long review of Mariano's book reaffirming the superiority of the Christian religion over Buddhism (he considered above all the Tibetan tradition), as far as the metaphysical problem is concerned, and attempting to bring the concept of Nirvana to the Christian idea of "eternal peace" (1891: 740). Catellani appreciated the moral refinement of the Buddhist teachings, which can be compared to Christianity, but to him the weakness of Buddhist metaphysics cannot back up an effective moral system. He even criticizes the pacific attitude of a religion which cannot impose itself on the masses, which cannot avoid religious syncretism and idolatry, and cannot survive "in the 
struggle for existence" (1891: 5). Catellani paid a special attention to the recent spread of Buddhism in the Western world, a "neo-Buddhism" which connects mysticism and science. This new interest in Buddhism, Catellani wrote, was caused by the new theories of evolution, the increasing skepticism in modern European society and the eternal, human need for mysticism. We can see very clearly that Mariano and Catellani were not fighting Buddhism in itself, but rather the fear of its seeping beyond the academic milieu into society, among "cultivated Western gentlemen." (Catellani 1891: 33) More precisely, the Buddhism they were fighting is the one proposed by the Theosophical Society (see the next paragraph) which mingled mysticism and science, Buddhist elements and Western esotericism.

Ten years later, in 1900, Raffaele Mariano published a revised version of his book Cristo, il Buddha e altri Iddii dell'Oriente (Christ, Buddha and other Oriental Gods), adding some chapters concerning the recent Italian and European debate. The aim of this new version of his study was a declared apology of the Christian religion and a defense against the threat of the modern world.

\section{Spirituality of Buddhism}

The essays of Puini, de Gubernatis, Pavolini and Teza prove that for most of the nineteenth century Buddhism in Italy was the concern above all of philologists, philosophers and scholars. Even most general books on Buddhism were for educated and learned readers, interested in art, history and culture. In the last decade of the nineteenth century something changed. According to Mariano and Catellani, Buddhism became a topic present even in everyday gentlemanly discourse, so that it was felt as a menace to the Christian religion. This threat came from works of philologists and philosophers, but now it concerned a broader public, with little if anything to do with philosophy and academe. Buddhism, as we have seen in de Gubernatis' play Buddha (see above the paragraph 'Scientific and anthropological approaches'), was no longer a philosophical subject but a general, artistic and cultural topic, even an existential model.

It seems that Buddhism fulfilled the need for mysticism and spirituality at a time when Western society became richer and traditional values were questioned by scientific progress. It is noteworthy that this existential or religious experience of Buddhism, even beyond its academic boundary, was based on studies, academic material or apologetic books but it did not rely on direct experience or knowledge of the Buddhist religion actually practiced by Asian people.

In 1875, Olcott and Blavatsky founded the Theosophical Society in New York and in 1880 the founders converted to Buddhism. It was the first organized group to introduce Indian beliefs and rituals into Western society. The Theosophical Society mixed Western mysticism and esoteric traditions, neo-Platonic and Buddhist ideas with a spiritual version of evolutionism and positivism. In this way 
the Theosophical Society became an important agency for presenting Buddhism to the Western world, answering its need for spirituality. At the same time it became a concrete opportunity for interreligious reflection. In this way Buddhism presented itself as a religious and spiritual experience and as a kind of current topic for people of the American, British and German middle classes. Buddhism reached a larger public and, from then on, its form of transmission was not only the academic essay. This new religious and spiritual attitude touched, to a certain degree, the Italian public, too.

In 1900, the Theosophical Society published as Italian edition of $\mathrm{Il}$ Buddhismo esoterico o positivismo indiano (Esoteric Buddhism or Indian Positivism) by Alfred Percy Sinnett (1883) in a translation by Mme. Lemaitre from the French version. In this book esotericism, spiritualism and Buddhist facts and principles are strangely intertwined and the esoteric aspects, faith in a secret of the universe and in a kind of old wisdom for a select few, is predominant. This book demonstrates the need for spirituality in Italy at the end of the nineteenth century.

Responding to the same need, in 1897 Giuseppe de Lorenzo translated Catechismo buddistico [Buddhist Catechism] from the German into Italian. Subhadra Bhikshu, the author of this didactic handbook, following the most recent philological ideas, privileged the Pali canon, since it is considered as preserving the original teachings of the Buddha. According to Karl Eugen
Neumann and his translations from Pali, De Lorenzo renders the Italian name of the Enlightened as 'Buddo' instead of the common 'Buddha' (Bhikshu 1897: IV). The book contains basic Buddhist tenets from the Pali canon and its declared aim is to explain Buddhist philosophy to a general readership. Actually this handbook presents the main features of Theravāda Buddhism in the structure of the Christian catechism, and Buddhist history and doctrine are accurately explained in 173 plain questions and precise answers. The exposition is very clear and easy and the author stresses the moral aspect of Buddhist thought: its purpose to free mankind from suffering, its specificity in comparison with revealed religions, its compatibility with other religions and with a scientific view of reality:

QUESTION: What is the main difference between the Buddha's teachings and other religions?

ANSWER: Buddhism teaches the highest goodness and wisdom, without intervention of a personal god; the highest knowledge, without revelation; the moral order of the world and a justice which is realized necessarily on the basis of natural laws and of our own essence; continuity of our being, without an immortal soul; (..) a redemption, in which everyone redeems himself, and which, without prayers, sacrifices, penances and external acts, without priests, without saints, without divine Grace, can be obtained and conquered only by 
himself, in this life and on this earth (Bikhshu 1897: 64).

The purpose of this catechism is clearly religious and this fact demonstrates the great change which occurred in Italy in the last decade of the nineteenth century. Now Buddhism was not only an issue for scholars and some cultivated men, but a cultural and religious fact which should concern "all educated persons interested in the greatness and beauty of the Buddhist conception of the world" (Bikhshu 1897: XIV). The author and the Italian translator (in the preface of the second edition, 1922) considered and appreciated the scientific production Buddhism of the last two decades of the nineteenth century in Germany and in Italy. The confessional spread of Buddhism seemed to be a continuation of its philological and philosophical understanding.

\section{Conclusion}

In the first seventy years of the nineteenth century, through Catholic missionaries' reports and various documents, Buddhism spread through Italy rather slow. From a generic and imprecise understanding, the school of Turin developed a philological approach to Indian texts. French, German and English translations and studies became the basis of an original and autonomous interpretation. Buddhism was an academic issue, and generally there were no full translations of texts and studies from European languages into Italian, except the excerpts presented in Italian studies. In the last thirty years of the nineteenth century Italian scholars like Puini and de Gubernatis use Tibetan and
Chinese texts as the basis for a philosophical and cultural approach to Buddhist studies or which a scientific study of Buddhism was founded.

In 1883 , the edition of the Pali canon by the King Chulalongkorn marked a new philological and philosophical discovery of the genuine message of the Buddha. Teza shows its importance to the scientific community and Pavolini's book presents a consistent and complete view of the topic.

In the last decade of the nineteenth century, interest in Buddhism spread beyond academic circles and became a cultural fact concerning a large member of readers, from scholars to cultivated men. Beginning in 1890 , there was a certain reaction against Buddhism among some parts of Italian culture. On one hand, Buddhism reached a larger public, it is felt to be a threat to Christian values and traditions. On the other hand the need for spirituality and the changing social context made Buddhism and Buddhist principles a part of a new spiritual experience of life, independent from the scientific and historical understanding of it.

The new century began with a great number of studies on Buddhism. Translations of Buddhist texts from the Pali canon became more and more common and available to non-academic readers. The approach became more philologically correct and philosophically relevant. At the same time Buddhism as a spiritual experience took a greater place in Western society, even independent from its presence in the scientific and cultural debate. This is the period which Botto 
called the third phase of the study of Buddhism (1985: 175), in which scholars fully developed an adequate and critical attitude to Buddhism, founded on the historical, philological and theoretical bases we have considered.

\section{Sources}

I present here the complete list of writings, essays and books on Buddhism published in Italy (exceptions are the unpublished report from 1776 of Father Percoto and de Gubernatis' study published in France) up to 1900. I follow chronological order and the list, so far as I could verify, is almost complete. We have to take into account that some writings have been lost. Some entries are still incomplete because I was not able to find the document or to identify it better. So I also include in this bibliography some texts which have been quoted in the Italian debate but about which we, today, do not have precise data and details. I use the original Italian title of documents; the English translation is given above in the essay when the text is cited.

Catellani, Enrico. 1891. Buddismo orientale e Buddismo europeo I-IV. $L$ 'ateneo veneto. (14) 2 (3-4): 713-742.

Catellani, Enrico. 1892. Buddismo orientale e Buddismo europeo V- VII. L'ateneo veneto. (14) 1 (2-3) 1-33.

De Gubernatis, Angelo. 1867a. Piccola enciclopedia indiana. Torino: Loescher.

De Gubernatis, Angelo. 1867b. Memoria intorno ai viaggiatori italiani nelle Indie Orientali dal secolo XIII a tutto il
$X V I$. Firenze: Tipografia Fodratti.

De Gubernatis, Angelo. 1876a. Manoscritti indiani del Museo Borgiano nel Collegio di Propaganda. Bollettino Italiano degli Studi Orientali. 1 (4-5): 82-85.

De Gubernatis, Angelo. 1876b. Matériaux pour servir à l'histoire de études orientales en Italie. Paris: Leroux.

De Gubernatis, Angelo. 1877. Enciclopedia Sinico-Giapponese (fascicolo primo). Notizie estratte dal Wa-Kan, San-sai, Tu-ye intorno al buddhismo per Carlo Puini. Firenze, Successori Le Monnier. Bollettino Italiano degli Studi Orientali. 1 (22): 435.

De Gubernatis, Angelo. 1883. Letteratura Indiana. Milano: Hoepli.

De Gubernatis, Angelo. 1902. Buddha. Dramma in cinque atti in versi. Roma: Tipografia Cooperativa Sociale.

Gorresio, Gaspare. 1845. Buddhismo Indico. Lettera del Cavalier Gaspare Gorresio al Cavalier Costanza Gazzera, segretario della Reale Accademia delle Scienze. Gazzetta Piemontese. 22.

Griffini, Michelangelo. 1781. Della vita di Monsignor Gio. Maria Percoto [...] missionario ne' regni di Ava e di Pegu libri tre scritti dal padre M. G. Udine: Gallici Fratelli.

Kerbacher, Michele. 1882a. La scienza delle religioni, Napoli. 
Kerbacher, Michele. 1882b. La scienza delle religioni. Discorso per l'inaugurazione degli studii. Napoli: Accademia Reale delle Scienze.

Kerbacher, Michele. 1900. Leggende Buddhistiche del Mahabharata. Atti dell'Accademia Pontaniana. (30) 5: 2-71.

Mariano, Raffaele. 1890. Buddismo e cristianesimo: studio di religione comparata. Napoli: Tipografia della Regia Universita.

Mariano, Raffaele. 1900. Cristo, il Buddha e altri Iddii dell'Oriente. Studi di religione comparata, vol. I. Firenze: Barbera.

Pavolini, Paolo Emilio. 1895. Le fonti del Devadhamma-jataka.

Pavolini, Paolo Emilio. 1898a. Buddismo. Milano: Hoepli.

Pavolini, Paolo Emilio. 1898b. A Malay Parallel to the Culla-Paduma-Jataka. JRAS. p. 375.

Pavolini, Paolo Emilio. 1899. Sulla leggenda dei quattro Pratyekabuddha. Actes du XIIme Congrès des Orientalistes, Roma. 1: 129-137.

Pavolini, Paolo Emilio. 1900. A proposito della triglotta buddhistica. Giornale della Società Asiatica Italiana. 13: 87-88.
Percoto, father Maria. 1776 . Kammuva, ossia trattato della ordinazione dei Talapoini del secondo ordine detti Pinzi. (Unpublished).

Puini, Carlo. 1871a. Studi sulle religioni dell'Estremo Oriente di Carlo Puini, alunno dell'Istituto degli Studi Superiori Pratici e di Perfezionamento di Firenze (Capo I, Il Buddhismo). Archivio per l'Antropologia e la Etnologia. 1: 214-238.

Puini, Carlo. 1871b. Studi sulle religioni dell'Estremo Oriente di Carlo Puini, alunno dell'Istituto degli Studi Superiori Pratici e di Perfezionamento di Firenze (Capo II, Dell'opera del Buddha). Archivio per l'Antropologia e la Etnologia. 1: 340-357.

Puini, Carlo. 1872a. Studi sulle religioni dell'Estremo Oriente di Carlo Puini, (Capo III, Metafisica Buddhica). Archivio per l'Antropologia e la Etnologia. 2 (1): 41-66.

Puini, Carlo. 1872b. Studi sulle religioni dell'Estremo Oriente di Carlo Puini, (Capo IV, Propagazione e svolgimento delle Dottrine Buddhiche). Archivio per l'Antropologia e la Etnologia. 2 (4): 363-383.

Puini, Carlo. 1872c. I sette genii della felicità. Notizia sopra una parte del culto dei giapponesi. Firenze:

Successori Le Monnier.

Puini, Carlo. 1873. Il nirvana. Archivio di antropologia ed etnologia. 3 (3-4). 
Puini, Carlo. 1876. Di una relazione inedita del viaggio al Tibet del $\mathrm{P}$. Ippolito Desideri da Pistoia, scritta da lui stesso. Bollettino Italiano degli Studi Orientali. 1: 33-42.

Puini, Carlo. 1877. Enciclopedia sinicogiapponese : Notizie estratte dal WaKan San-Sai Tu-Ye sulla religione, gli usi, i costumi, la storia, l'etnologia e la geografia della Cina e del Giappone. Firenze: Successori Le Monnier.

Puini, Carlo. 1878. Buddha, Confucio, Lao Tse: notizie e studi intorno alle religioni dell'Asia orientale. Firenze: Sansoni.

Puini, Carlo. 1882. Saggi di storia della religione. Firenze: Le Monnier.

Puini, Carlo. 1891. Le origini della civiltà secondo la tradizione e la storia dell'estremo oriente. Firenze: Le Monnier.

Puini, Carlo. 1897. Saddharma Pundarika nella versione cinese. Studi Italiani di filologia indoiranica. 1-2 Firenze: Carnesecchi.

Puini, Carlo. 1899. Il Buddhismo nel Tibet secondo la Relazione inedita del viaggio del P. Ippolito Desideri, in Studi Italiani di Filologia Indo-Iranica. (3) 3: 1-63.

Puini, Carlo. 1899. Il P. Ippolito Desideri e i suoi viaggi nell'India e nel Tibet (1712-1727). Studi Italiani di Filologia Indo-Iranica. (3) 3: XXVI-XXXII.
Sinnett, Alfred Percy. 1900. Il buddhismo esoterico o Positivismo indiano, translated from the French text by $\mathrm{C}$. Lemaitre edited by the Theosophical Lodge of Rome. Roma: Libreria teosofica editrice.

Subhadra Bhikshu. 1897. Catechismo buddistico per avviamento nella dottrina di Gotamo Buddo. Translated by G.D.L., Napoli: E. Marghieri.

Tagliabue, C. 1894. La dottrina buddhista sulla trasmigrazione. L'oriente. (1) 3: 171-178.

Teza, Emilio. 1872. A Siddarta Suddodanide, il Budda (imitazione di un inno indiano), Pisa.

Teza, Emilio. 1882. Sul lokaniti. Studi sulla Gnomologia Buddiana. Memorie del Regio Istituto Lombardo. 14 (5): 125-134.

Teza, Emilio. 1892. La Crisna dei Panduidi nelle tradizioni buddiane, Nota. Atti del Regio Istituto Veneto. 51 (7-4): 1442-1451.

Teza, Emilio. 1895a. Il physiologos presso a' buddiani. Atti e Memorie della Regia Accademia delle Scienze, Lettere ed Arti di Padova. 9: 83-86.

Teza, Emilio. 1895b. In un eremitaggio di frati buddiani: leggende magadesi. Atti e Memorie della Regia Accademia delle Scienze, Lettere ed Arti di Padova. 11: 131-147. 
Teza, Emilio. 1895c. Il Tipitaka dei Buddiani nel Siam. Atti del Regio Istituto Veneto, 1895-1896. 212-223.

Teza, Emilio. 1895d. Voci birmane nella vita del padre G. M. Percoto scritta dal padre M. A. Griffini. Atti del Regio Istituto Veneto di scienze, lettere ed arti. (7) $7: 82-88$.

Teza, Emilio. 1896. Il Tipitaka dei Buddiani stampato nel Siam. (Enclosed in Tipitakam dei Buddiani, Bang-kok, 1894. donated by King Chulalongkorn to the Royal Academy of Science of Turin) 1894) Venezia: Tipografia Ferrari.

\section{The Siamese Edition of the Tipitaka}

Tipitaka. 1894. Ordered by H. M. the King Chulalongkorn. Bangkok.

I have been able to identify and find two complete Siamese editions of the Tipitaka edited by $\mathrm{H}$. M. the King Chulalongkorn and donated to Italian universities and institutions. In one case the title was displaced in the catalog because of a wrong transcription. In both cases the institutions hardly realize the importance of the books they possess. Today the state of conservation of both these precious books is discrete. The handwritten inscription in Italian "Buddhist Tipitaka (in Siamese characters) Bangkok, 1894" tells the title and the origin. This copy is now in the possession of the National Library of Turin. Another copy of Tipitaka given to the Royal Academy of Science of
Turin is still the possession of the Academy.

\section{References}

Botto, Oscar. 1985. Appunti per una storia degli studi Buddhisti in Italia.

Orientalia Iosephi Tucci Memoriae Dicata, pp. 175-189. Roma: Istituto Italiano per il Medio ed Estremo Oriente.

Botto, Oscar. 1993. Gli studi di orientalistica. L'Università di Torino. Profilo storico e istituzionale, edited by Francesco Traniello, pp. 134-140. Torino: Pluriverso.

Botto, Oscar. 1997. Early Scholars of Asia and Buddhism in Connection with Oriental Studies in Italy. Living a Life in Accord with Dhamma: Papers in Honor of Professor Jean Boisselier on His Eightieth Birthday, edited by Natasha Eilenberg, M. C. Subhadradis Diskul, Robert L. Brown, preface of $\mathrm{H}$. R. H. Princess Maha Chakri Sirindhorn, pp. 95-104. Bangkok: Silpakorn University.

Crosby, Kate. 2014. Theravada Buddhism. Continuity, Diversity, and Identity. Chichester: Wiley Blackwell.

Filoramo, Giovanni. 1997. Le religioni dell'Asia. Il Buddhismo. Storia delle religioni, edited by G. Filoramo. RomaBari: Laterza.

Harvey, Peter. 1990. An Introduction to Buddhism. Teachings, History and 
Practices. Cambridge: Cambridge University Press.

Nada, Narciso. 1993 La Restaurazione. L'Università di Torino. Profilo storico $e$ istituzionale, edited by Francesco Traniello, pp. 34-39. Torino: Pluriverso.

Nyantiloka. 2004. Buddhist Dictionary. A Manual of Buddhist Terms and Doctrines. Chiang Mai: Silkworm Book.

Piano, Stefano. 2010. Il sanscrito e la cultura dell'India nell'Università di Torino: la nascita dell'indologia. DOST Critical Studies. (The Department of Oriental Studies, University of Turin) 8: 1-16.

Pugliese Carratelli, G. 1984. L'indianistica a Napoli tra l'Otto e il Novecento. $L a$ conoscenza dell'Asia e dell'Africa in Italia nei scoli XVIII e XIX, edited by Ugo Marazzi, 2-1: pp. 5-17. Napoli: Istituto Universitario Orientale.

Sheravanichkul, Arthid. 2012. Thai Ideas about Hīnayāna/Mahāyāna: Correspondence between King Chulalongkorn and Prince Narisranuvattiwong. How Theravāda is Theravāda? Exploring Buddhist Identities, edited by Peter Skilling, Jason A. Carbine, Claudio Cicuzza, Santi Pakdeekham. 415-441. Chiang Mai: Silkworm Books.

Warren, Henry Clarke. 1896. Buddhism in Translation. Harvard: Harvard University Press. 